\title{
O Diálogo na Educação Ambiental: uma Síntese A Partir de Martin Buber, David Bohm, William Isaacs e Paulo Freire ${ }^{1}$
}

\author{
The Dialogue in Environmental Education: a Synthesis From Martin Buber, David \\ Bohm, William Isaacs and Paulo Freire
}

\section{El Diálogo en la Educación Ambiental: una Síntesis A Partir de Martin Buber, David Bohm, William Isaacs y Paulo Freire}

\author{
Rafael de Araujo Arosa Monteiro ${ }^{2}$ \\ Marcos Sorrentino ${ }^{3}$
}

\begin{abstract}
Resumo
O diálogo se constitui enquanto importante princípio e objetivo da Educação Ambiental (EA), sendo relevante o aprofundamento de sua compreensão teórica e metodológica. Buscamos neste artigo apresentar uma síntese, a qual partiu do conceito de existência dialógica de Martin Buber para a proposta de uma espiral dialógica, composta por diferentes caminhos, estando entre eles os grupos de diálogo de David Bohm, também estudados por William Isaacs, e os círculos de cultura de Paulo Freire. A partir disso, realizou-se a união dos elementos existentes em cada caminho em duas categorias, compostas por um conjunto de perguntas-indicadoras, que podem subsidiar o desenvolvimento, execução e avaliação de processos de EA, potencializando o processo dialógico. Ademais, sugere-se um procedimento metodológico baseado nos caminhos supracitados, caracterizado por quatro momentos: codificação; observação da codificação ou escuta genuína; descrição da codificação; e "readmiração" das admirações, observando as sensações corporais e emoções.
\end{abstract}

Palavras-chave: Diálogo. Educação Ambiental. Existência dialógica. Espiral dialógica. Indicadores.

\begin{abstract}
The dialogue constitutes an important principle and objective of Environmental Education (EE), being relevant the deepening of its theoretical and methodological understanding. In this article we present a synthesis, which began with Martin Buber's concept of dialogical existence to create the idea of a dialogical spiral composed by different paths, among them the dialogue groups of David Bohm, also studied by William Isaacs, and the circles of culture of Paulo Freire. From this, the elements in each path were combined into two categories, composed by a set of questions-indicators, which can support the development, execution and evaluation of EE processes, enhancing the dialogic process. In addition, a methodological procedure based on the aforementioned paths is suggested, characterized by four moments: codification; observation of codification or genuine listening; description of the codification; and "re-admiration" of admirations, observing bodily sensations and emotions.
\end{abstract}

Keywords: Dialogue. Environmental Education. Dialogical existence. Dialogical spiral. Indicators.

\section{Resumen}

El diálogo se construye como importante principio y objetivo de la Educación Ambiental (EA), siendo relevante la profundización de su comprensión teórica y metodológica. Buscamos en este artículo presentar una síntesis, que surgió a partir de la existencia dialógica de Martin Buber para crearse la idea de una espiral dialógica, compuesta por diversos caminos, entre ellos los grupos de diálogo de David Bohm, también estudiados por

\footnotetext{
${ }^{1}$ Este artigo é fruto da dissertação de mestrado desenvolvida pelo primeiro autor, sob orientação do segundo autor, junto ao Programa de Pós-graduação em Ciência Ambiental da Universidade de São Paulo.

${ }^{2}$ Doutorando e mestre pelo Programa de Pós-Graduação em Ciência Ambiental (PROCAM-USP) e pesquisador do Laboratório de Educação e Política Ambiental (ESALQ/USP). E-mail: rafael.araujo.monteiro@usp.br

${ }^{3}$ Professor e ambientalista, coordena o Laboratório de Educação e Política Ambiental da Esalq/USP e foi diretor de Educação Ambiental do Ministério do Meio Ambiente da República Federativa do Brasil de 2003 a 2008 . Email: macsor@usp.br
} 
William Isaacs, y los círculos de cultura de Paulo Freire. A partir de eso, se unieron elementos existentes en cada camino en dos categorías, compuestas por un conjunto de preguntas-indicadoras, que pueden subsidiar el desarrollo, ejecución y evaluación de procesos de EA, potencializando el proceso dialógico. Además, se sugiere un procedimiento metodológico basado en los caminos supra citados, caracterizado por cuatro momentos: codificación; observación de la codificación o escucha genuina; descripción de la codificación; "re-admiración" de las admiraciones, observando las sensaciones corporales y emocionales.

Palabras-clave: Diálogo. Educación ambiental. Existencia dialógica. Espiral dialógica. Indicadores.

\title{
1. Educação Ambiental e Diálogo
}

De acordo com importantes documentos nacionais (Programa Nacional de Educação Ambiental [ProNEA] e Programa de Formação de Educadoras(es) Ambientais [ProFEA]) (ÓRGÃO GESTOR DA PNEA, 2006, 2014) e internacionais (Tratado de Educação Ambiental para Sociedades Sustentáveis e Responsabilidade Global [TEASS]) (FÓRUM GLOBAL DAS ONGs, 1992) de Educação Ambiental (EA), o diálogo se constitui, ao mesmo tempo, enquanto importante princípio e objetivo da mesma.

Sorrentino et. al. (2013) afirmam que estimular o diálogo constitui um desafio e uma necessidade para a realização de uma EA "que fortalece e confere autonomia e confiança aos indivíduos, que promove a coexistência equilibrada entre as realidades e contextos pessoais e coletivos, entre o moderno e as tradições, entre a tecnologia e o jeito simples de ser" (p. 37). Sorrentino (2014) complementa enunciando que o objetivo maior dos processos educadores ambientalistas é a promoção do acesso ao diálogo empoderador entre os sujeitos que deles participam.

\begin{abstract}
O diálogo crítico e acolhedor que permite a tomada de posições pautadas nas próprias convicções e na capacidade de revê-las e incrementá-las em direção à construção do seu projeto de futuro, dos seus sonhos e utopias. Diálogo que permita abrir-se ao próximo e planejar e avaliar juntos. Diálogo consigo mesmo, com os ventos, com as árvores, com os animais, com outros seres e energias que povoam os nossos sentimentos, a nossa alma e enriquecem o nosso espírito. Diálogo com a sociedade, procurando entende-la criticamente, historicamente, conjunturalmente, em toda a sua estrutura e contradições, de forma a sentir-se potente para transformála com os outros e para o bem de todos. Diálogo voltado à superação das posturas e ações competitivas, intolerantes, homogeneizadoras, machistas, massificantes, imediatistas, predatórias e gananciosas, para o incremento dos conhecimentos e compromissos de toda a humanidade e de cada um com a VIDA, a democracia, a solidariedade, o repúdio a todo e qualquer tipo de totalitarismo, a diversidade, a paz, a justiça, o amor e a emancipação humana (SORRENTINO, 2014, p. 147).
\end{abstract}

Figueiredo (2003, 2006), por sua vez, apresenta a concepção de uma Educação Ambiental Dialógica (EAD) pautada nas ideias freireanas, afirmando a importância de se trabalhar a problemática ambiental a partir das várias dimensões que compõem a realidade: social, econômica, cultural, científica, tecnológica, ética, espiritual e ecológica, reconhecendo a complexidade e a importância de se considerar a totalidade, rompendo com o paradigma fragmentador cartesiano. Nesse sentido, agrega a essa concepção de EA a Perspectiva EcoRelacional (PER), a qual enfatiza a relação como eixo principal do processo educador.

Trabalhando também a partir das ideias freireanas, Logarezzi (2010) sugere uma Educação Ambiental acompanhada pelo qualificativo "crítico-dialógica". A perspectiva crítica aqui "inclui a denúncia das contradições sociais enquanto base da destruição ambiental, e coloca esta relação como fundamento para a ação de enfrentamento das contradições, sendo ação anunciadora e portanto transformadora" (p. 13). O qualificativo "dialógica" traz em si o reconhecimento da incompletude humana, a necessidade de tomada de posição política frente 
à realidade e coloca a interação/relação como o elemento central do processo educador ambientalista.

No entanto, Andrade e Sorrentino (2014a, 2014b) alertam para um perigo bastante sério em se tratando da Educação Ambiental. Esta se constitui enquanto uma invenção ocidental para tentar mitigar os problemas ambientais criados pelo próprio Ocidente, o qual se caracteriza por uma postura ativa de dominação do Outro, considerado objeto a ser catequizado, no caso dos indígenas, ou impulsionado em direção ao progresso, no caso dos países em desenvolvimento.

Esse processo de colonização tem a educação como forte instrumento de dominação, na medida em que prescreve princípios, atitudes e comportamentos adequados do ponto de vista do colonizador. E, muitas vezes, mesmo que de forma não intencional, os educadores se constituem enquanto agentes de tal processo, pois "à medida que compreendemos o outro enquanto objeto que necessita de orientação e supervisão, nós sentimos que é nosso dever, mesmo subconscientemente, impor nossos valores e interesses aos outros" (ANDRADE; SORRENTINO, 2014b, p. 148, tradução nossa). Dessa forma, o diálogo se constitui num modo de se libertar desse modelo colonizador, pois

Ao propiciar as condições em que as influências sutis e tácitas sobre o pensamento sejam alteradas, o diálogo possibilita uma transformação da natureza da consciência, permitindo a emergência de novos tipos de inteligências individuais e coletivas, em substituição dos padrões mentais existentes quando as questões surgiram. E esse novo tipo de inteligência pode potencializar a ação [transformadora da realidade] (SORRENTINO et al., 2013, p. 41).

Ademais, ao assumir o diálogo enquanto um princípio do fazer educativo ambiental, é necessário a identificação dos obstáculos existentes no encontro dialógico e o constante exercício em busca de sua resolução, o que demanda tempo e métodos diferentes dos utilizados pelo sistema educacional vigente (ANDRADE; SORRENTINO, 2014a), haja vista que

Pedagogias ocidentais tradicionais são marcadamente não dialógicas, hierárquicas e isoladoras, de modo que a realização do diálogo nos convida a pensar diferente, em dinâmicas inovadoras que possam nos ajudar a superar nossas distâncias em relação aos outros (ANDRADE; SORRENTINO, 2014a, p. 670).

Assim, um dos principais desafios postos hoje para a EA é a elaboração e implementação de pedagogias dialógicas em contextos formais e não formais de educação, de forma que as(os) educadoras(es) ambientais devem estar sempre se questionando sobre sua prática à luz da concepção dialógica. Para isso, devem reconhecer a posição social e histórica que ocupam, ou seja, sua marca ocidental para que não se iludam acreditando serem agentes promotores de mudanças, quando na verdade suas ações perpetuam o status quo (ANDRADE; SORRENTINO, 2014a).

Para isso, é fundamental a realização de pesquisas que aprofundem a compreensão do diálogo, bem como sua teoria operacional, buscando a formulação de indicadores que auxiliem no processo de entendimento da dialogicidade no fazer das(os) educadoras(es) ambientais (ANDRADE, 2013; ANDRADE; LUCA; SORRENTINO, 2012; AVANZI, 2005; LIMA, 2014; LUCA; ANDRADE, 2013; ROESE, 2014; SILVA, 2016; SOUZA, 2017). Nesse sentido, este artigo visa oferecer uma síntese a partir das ideias de Martin Buber, David Bohm, William Isaacs e Paulo Freire sobre o diálogo.

\section{Diálogo: o conceito}

A etimologia da palavra diálogo vem do grego diálogos. Dia significa "através" e logos "a palavra" ou "significado da palavra", sugerindo a imagem "de uma corrente de 
significados que flui entre nós e por nosso intermédio; que nos atravessa enfim" (BOHM, 2005, p. 34). Assim, o diálogo pode ser entendido como o fluir de significados por meio da palavra.

Também pode ser entendido como:

uma conversa com um centro e não lados. É um caminho para pegar a energia de nossas diferenças e canalizá-la em direção de algo que nunca tenha sido criado antes. Isso nos retira da polarização e nos conduz para um senso comum maior e, desse modo, é um meio para acessar a inteligência e o poder de grupos de pessoas. (ISAACS, 1999, p. 19, tradução nossa).

O diálogo possibilita que as pessoas pensem juntas, de forma a não se prender em opiniões preestabelecidas e se livrando das "certezas" adquiridas ao longo da vida, permitindo mudanças na identidade dos envolvidos em tal processo, uma vez que percebem ser mais do que pensavam ser (ISAACS, 1999, 2012).

Nesse sentido, o diálogo pode se caracterizar por ser o "encontro dos homens [e mulheres], mediatizados pelo mundo, para pronunciá-lo" (FREIRE, 1981, p. 93, grifo do autor), pronúncia que se dá por meio da palavra verdadeira, a qual se constitui por ser simultaneamente ação e reflexão, ou seja, práxis. Uma vez pronunciado, o mundo volta problematizado para os pronunciantes exigindo deles um novo pronunciar (FREIRE, 1981). Na medida em que esse ciclo virtuoso vai se desenvolvendo, a transformação do mundo vai ganhando cada vez mais possibilidade de ocorrer, uma vez que os atores envolvidos no diálogo estão desvelando a realidade, objetivando-a, e reconhecendo, por sua vez, a limitação do conhecimento que possuem, o que permite o desenvolvimento do pensar e agir críticos (FREIRE; SHOR, 1986). Portanto, o diálogo é uma exigência existencial, na medida em que "se é dizendo a palavra com que, "pronunciando" o mundo, os homens [e as mulheres] o transformam, o diálogo se impõe como caminho pelo qual os homens [e as mulheres] ganham significação enquanto homens [ou mulheres]" (FREIRE, 1981, p. 93).

Dessa forma, fica claro que diálogo não é o mesmo que discussão ou debate. Nessas modalidades de conversa, estabelece-se uma disputa de ideias, na qual se tem um vencedor e um perdedor. Numa conversa dialógica ocorre exatamente o oposto, só há vencedores. Além disso, o diálogo permite o surgimento de novas compreensões, a partir do compartilhamento do significado. "Esse significado compartilhado é a 'cola' ou 'amálgama' que mantém juntas as pessoas e as sociedades" (BOHM, 2005, p. 34).

\subsection{A existência dialógica e sua espiral}

Os três autores supracitados (David Bohm, William Isaacs e Paulo Freire) desenvolveram suas concepções de diálogo tendo como uma de suas principais referências o filósofo e educador austríaco Martin Buber (1878-1965). Este apresentou a ideia de uma existência dialógica, a qual traz em si uma concepção mais ontológica do diálogo.

Buber (2014) enuncia dois tipos de existência: a monológica e a dialógica. A primeira se caracteriza por um dobrar-se em si mesmo, por uma objetificação do Outro, reconhecido apenas como um meio para a vivência própria. Já a existência dialógica é caracterizada pela relação de reciprocidade entre os Seres, de forma que o voltar-se para o Outro se institui e, assim, a comunhão acontece. Aqui, a postura que se faz presente é a da tomada de conhecimento íntimo do Outro, o que significa "experienciá-lo como uma totalidade e, 
contudo, ao mesmo tempo, sem abstrações que o reduzam, experienciá-lo em toda a sua concretude" (BUBER, 2014, p. 147, grifo nosso).

Ao entrar nesse tipo de relação, é possível reconhecer o Outro como ele é e não como parece ser, implicando assim numa responsabilidade dialógica, genuína, que demanda por sua vez um responder verdadeiro, entendido como "responder ao que nos acontece, que nos é dado ver, ouvir, sentir" (BUBER, 2014, p. 49), ou seja, enunciar aquilo que de verdadeiro existe dentro de cada um.

Essa existência dialógica é caracterizada pela palavra-princípio Eu-Tu. A relação é o que marca essa palavra-princípio, dando-se numa troca muito profunda na qual o $\mathrm{Eu}$ e o $\mathrm{Tu}$ participam ativamente e, ao fazê-lo, estão inteiros, em suas totalidades, e não fragmentados por uma necessidade particular. "Quem diz TU [...] permanece em relação" (BUBER, 1979, p. 29, grifo nosso).

Outro ponto importante da relação Eu-Tu é que o Tu se encontra com o Eu. Não há uma busca deste por aquele. No entanto, ao se encontrarem, é o EU que entra em relação imediata com o TU (BUBER, 1979).

A relação com o TU é imediata. Entre o EU e o TU não se interpõe nenhum jogo de conceitos, nenhum esquema, nenhuma fantasia; e a própria memória se transforma no momento em que passa dos detalhes à totalidade. Entre EU e o TU não há fim algum, nenhuma avidez ou antecipação; e a própria aspiração se transforma no momento em que passa do sonho à realidade. Todo meio é obstáculo. Somente na medida em que todos os meios são abolidos, acontece o encontro (BUBER, 1979, p. $33)$.

Buber (1979, p. 35) alerta que "a grande melancolia de nosso destino é que cada TU em nosso mundo deve tornar-se irremediavelmente um ISSO". Após o encontro, marcado por esse contato profundo, o Tu se torna um objeto, quantificável e descritível. "Cada TU neste mundo é condenado, pela sua própria essência, a tornar-se uma coisa, ou então, a sempre retornar à coisidade" (p. 35). Porém, esse é o processo pelo qual as relações do Eu acontecem, um entrelaçamento entre momentos que ora se estabelecem com o Tu e ora com o Isso. "Cada TU, após o término do evento da relação deve necessariamente se transformar em ISSO. Cada ISSO pode, se entrar no evento da relação, tornar-se um TU” (p. 42). Frente ao exposto, Buber (1979) afirma que nosso modo de vida está cada vez mais dominado pelo mundo do Isso e assim se faz necessário resgatar a dimensão do encontro com o $\mathrm{Tu}$, a busca pela existência dialógica, para que homens e mulheres não percam sua essência humana.

Nesse sentido, Freire, Bohm e Isaacs apresentam caminhos metodológicos para se viver uma existência dialógica. Para Freire (1981, 1983), tal existência se caracteriza pela ausência de opressão de um Ser pelo outro, na qual haja liberdade para que cada indivíduo possa se perceber num constante processo de vir a ser, no qual está sendo e, portanto, se constituindo enquanto ser humano. Para Bohm $(1980,2005)$ e Isaacs $(1993,1999)$, é aquela em que se rompe com a lógica mecanicista e fragmentadora do pensamento, adotando a ordem implicada.

Os caminhos metodológicos apresentados pelos autores se caracterizam por um exercício individual e coletivo que só se concretiza por meio da relação entre as pessoas, mediatizada pelo desvelamento da cultura a partir de uma compreensão da totalidade em que vivem. O caminho sugerido por Bohm $(2005)$ e Isaacs $(1993,1999,2012)$ é a constituição de grupos de diálogo, no qual um grupo de pessoas se reúne para realizar o exercício de suspensão dos pressupostos. Freire $(1981,1983)$, por sua vez, sugere como caminho os círculos de cultura, no qual os participantes realizam o exercício da codificação e descodificação.

Dessa forma, é possível perceber que a existência dialógica, proposta por Buber, se constitui enquanto um processo permanente e continuado e por isso não pode ser encarada 
como um estágio final a que se almeja chegar. Tal processo pode se dar por uma infinidade de caminhos, como os propostos por Freire, Bohm e Isaacs, ou outros, que permitam a cada pessoa viver em diferentes intensidades uma existência dialógica, criando o movimento de uma Espiral Dialógica (Figura 1).

Figura 1 - Espiral dialógica e espiral antidialógica

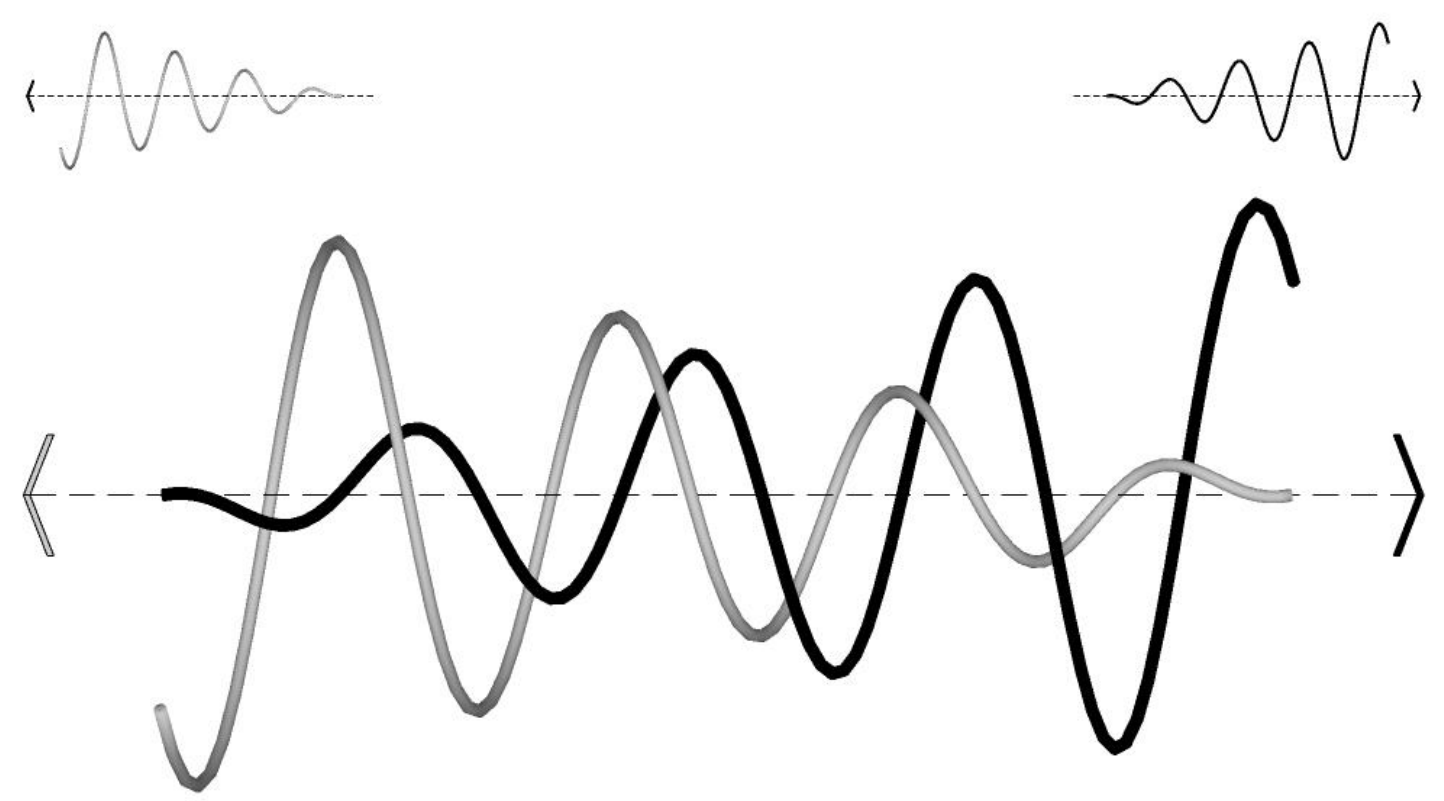

Fonte: Elaboração própria, com o auxílio do arquiteto Dhiego Torrano.

A Figura 1 mostra duas espirais opostas e sobrepostas, uma cinza e outra preta. Para exemplificar a explicação adotaremos aqui a espiral preta como a da existência dialógica e a espiral cinza como a da existência antidialógica. Observando a primeira, é possível notar que ela caminha da esquerda para a direita de modo crescente, aumentando a amplitude da espiral, o que representa o incremento da existência dialógica. Assim, em seu início, a existência dialógica é muito incipiente e em seu "fim" ela é predominante.

Em oposição está a espiral cinza antidialógica. Ela caminha da direita para esquerda de forma crescente, ou seja, em seu início há a incipiência da antidialogicidade e em seu fim a predominância. A sobreposição entre as espirais permite a compreensão de que quando a antidialogicidade predomina (canto esquerdo da figura) há uma incipiência da dialogicidade, e quando esta predomina (canto direito da figura) há uma incipiência daquela.

Portanto, caminhos que permitam o pensar e agir dialógico nos movem para o incremento da espiral dialógica, possibilitando a desconstrução da antidialogicidade dentro de nós. Por outro lado, caminhos obstaculizadores do diálogo nos levam a viver uma existência marcada pela antidialogicidade, distanciando-nos de uma vida em que exista a comunhão com o Outro (BUBER, 2014).

A seguir, serão apresentados detalhadamente os caminhos propostos por Freire, Bohm e Isaacs, constitutivos da espiral dialógica.

\subsection{Caminhos dialógicos}

\subsubsection{Grupos de diálogo}


David Bohm (1917-1992), físico teórico norte-americano, apresenta uma visão paradigmática que rompe com a estrutura mecanicista fragmentadora da realidade e das relações entre os Seres. Ele enuncia a existência de uma totalidade indivisa, a qual não se limita ao que podemos ver, sentir, cheirar etc., a que ele chama de Ordem Explicada, mas se constitui também por uma realidade mais sutil e profunda, denominada Ordem Implicada. Esta se caracteriza pela noção de que o todo está em tudo. Cada elemento contém, dobrado em si (implicado), a totalidade, o todo (BOHM, 1980).

Afirma que existe um movimento dessa totalidade, o Holomovimento, o qual permite que determinados aspectos da ordem implicada sejam relevados para nós, constituindo-se em ordens explicadas. Estas, por sua vez, podem voltar à ordem implicada, dobrando-se novamente. Esse movimento é o que caracteriza essa perspectiva de uma totalidade indivisa e traz um caráter de humildade muito grande frente ao conhecimento, pois nos mostra nossa incapacidade de abarcar esse todo, sendo possível, no entanto, considerá-lo ao se olhar para situações particulares, entendidas como subtotalidades relativamente autônomas. A grande superação aqui é o reconhecimento paradigmático de que não conhecemos tudo, de que "relevamos" certos aspectos da ordem implicada para explicar determinadas situações circunscritas a determinados contextos, mas que não podem se constituir enquanto generalizações (BOHM, 1980).

Nesse sentido, os grupos de diálogo para Bohm (2005) constituem um caminho possível pelo qual se desvela aspectos culturais, entendidos como manifestações relevadas da ordem implicada, para permitir a emergência de novas manifestações dessa ordem até então desconhecidas. Para isso, o autor propõe o exercício da suspensão dos pressupostos básicos que guiam as vidas das pessoas, os quais se caracterizam por suposições prévias a respeito dos mais variados temas, como relações interpessoais, religião, formas de viver a vida etc. (BOHM, 2005).

Em um grupo há diversas opiniões baseadas em pressupostos que foram construídos ao longo da história de vida de cada indivíduo, os quais costumam ser defendidos, sob uma carga emocional, quando questionados. Porém, no diálogo é possível substituir tal carga emocional por uma postura racional para se observar o que está por trás dos pressupostos (BOHM, 2005).

A imagem que Bohm (2005, p. 55) propõe é a de "imaginar tudo isso [os pressupostos] suspenso, pendurado diante de seus olhos de modo que possa observá-lo como o reflexo que vê quando está diante de um espelho". Para a realização desse exercício é preciso "que você se dê conta das conexões que existem entre os pensamentos que acontecem no diálogo, as sensações corporais e as emoções" (p. 55-56), pois ao perceber esse conjunto de elementos atuando, e geralmente bloqueando a comunicação, ao mesmo tempo em que se está atento ao conteúdo que é comunicado, ter-se-á realizado a suspensão.

Aprofundando tais ideias, William Isaacs (1999), estudioso do diálogo na concepção bohmiana e presidente de uma consultoria norte-americana chamada "Dialogos", afirma que há duas formas de realizar a suspensão. A primeira é compartilhando o conteúdo do pensamento, "é abrir, disponibilizar para si e para os outros o conteúdo de sua consciência para que você possa ver o que está acontecendo. [...] Para fazer isso você precisa localizar, nomear e então expor para os outros o que você conhece" (p. 142, tradução nossa). A segunda é entender o processo pelo qual o conteúdo do pensamento foi gerado, de forma que "ao observar os processos do meu pensamento desta forma, eu os transformo" (p. 144, tradução nossa).

A suspensão dos pressupostos torna possível a propriocepção (ou auto percepção) do pensamento, caracterizada pelo movimento de perceber a intenção de pensar. Os problemas da humanidade, para Bohm, se devem ao fato de o pensamento não possuir tal habilidade. Assim, "o ponto fundamental da suspensão é tornar a propriocepção possível, criar um 
espelho, de modo que você possa ver os resultados do seu pensamento" (BOHM, 2005, p. 63, grifo do autor), assim como reconhecer os limites dele (BOHM, 1980).

A dificuldade de realizar tal exercício se deve à fragmentação do pensamento e da compreensão de que ele não é ativo, que ocorre de forma natural, o que se constitui num erro, uma vez que é muito ativo e determina tudo que está à nossa volta. Além disso, "o pensamento defende seus pressupostos básicos contra as evidências de que pode estar equivocado" (BOHM, 2005, p. 41) Por isso, "o propósito do diálogo é percorrer todo o processo do pensamento e mudar o modo como ele acontece coletivamente" (BOHM, 2005, p. 38 grifo nosso).

Dessa forma, o exercício de suspender os pressupostos nos permite romper com o mecanicismo da nossa forma de pensar que condiciona e limita nossos pensamentos, fazendo com que não tenhamos essa noção do todo e de outras formas possíveis de Ser. Isso nos permite questionar as formas de pensar e agir que temos e, assim, ter novos insights, provenientes da ordem implicada (BOHM, 1980, 2005).

Considerando o exposto até aqui, fica claro que o diálogo exige e, ao mesmo tempo, promove um campo de conversação particular (ISAACS, 1999), diferente da discussão e debate, como já mencionado anteriormente (BOHM, 2005). Um campo de conversação pode ser definido como um espaço no qual há uma qualidade de energia e troca. Esse campo não pode ser criado, mas é possível produzir condições para que um bom campo emerja. Essas condições constituem o "contêiner", composto por aspectos internos, ou emocionais, como as posturas de cada pessoa em ouvir, respeitar, suspender e enunciar, e externos, ou físicos, como a acústica do local, a disposição circular do grupo, número de pessoas etc. Ou seja, o contêiner se caracteriza pelas "características relativamente observáveis dos campos" (ISAACS, 1999, p. 257, tradução nossa).

Sobre os aspectos externos, ou físicos, Bohm (2005) afirma que um grupo de vinte a quarenta pessoas é o ideal para se trabalhar. Nessa configuração grupal é possível constatar a presença de um microcosmo da cultura global, de forma que o significado coletivamente compartilhado começa a surgir. O desafio do diálogo é o de permitir que esse significado seja observado, criando um pensamento coletivo coerente, uma vez que o fato de existir no grupo muitas opiniões e pressupostos diversos implica num pensamento coletivo incoerente, no qual uns pensam $\mathrm{x}$, outros y e assim por diante sobre determinado assunto.

Outra condição externa para a ocorrência do diálogo é a disposição circular dos participantes, uma vez que tal arranjo não gera privilégios. Outro ponto importante é a frequência dos encontros. Podem ser semanais, quinzenais etc., e durar um, dois ou mais anos. No entanto, não se deve perpetuar um grupo de diálogo. O mais importante não é o tempo que dura, mas que se desenvolva num tempo suficiente para gerar mudanças em seus participantes (BOHM, 2005). Há também a importância da acústica do local do encontro para que todos consigam se ouvir bem, e da inexistência de elementos que possam distrair os participantes, perdendo o foco na conversa (ISAACS, 1999).

Sobre os aspectos internos, mentais ou emocionais, tem-se as quatro ações já mencionadas acima: ouvir, respeitar, suspender e enunciar (ISAACS, 1999). Bohm (2005) afirma que é muito importante que todos tenham a oportunidade de se expressar e de "ouvir livremente", sem preconceitos e sem interesse de influenciar os participantes da conversa, já que havendo tentativas de convencer ou persuadir o Outro, ter-se-á os pressupostos guiando a relação, a qual não terá o caráter de diálogo. Se as opiniões forem enunciadas, ouvidas, respeitadas e suspensas por todos os participantes do diálogo, uma mente comum surgirá, uma vez que ela será o resultado de todos os conteúdos existentes no grupo, formando assim um conteúdo compartilhado por todos.

Outro aspecto é o fato de não haver no diálogo forças coercitivas, representadas por figuras de autoridade, pois assim cria-se uma assimetria nas relações, de forma que a 
liberdade deixa de ser igual entre os participantes e por diversos motivos certos assuntos podem não ser tratados. Além disso, não deve haver também uma agenda com objetivos a serem alcançados, pois, uma vez definidos, se está, na verdade, assumindo pressupostos, os quais não serão questionados ao longo do processo e, consequentemente, restringirão o diálogo (BOHM, 2005).

Por outro lado, Bohm (2005, p. 51) afirma que

Podemos estabelecer propósitos de investigação, mas não estamos atrelados a um objetivo específico nem estabelecemos que o grupo inteiro deva ajustar-se indefinidamente a ele. [...] Nossa meta é, na realidade, comunicar-nos coerente e verdadeiramente; se você quiser, pode chamar isso de objetivo.

Tendo em vista que nossa sociedade está habituada a trabalhar com autoridade e objetivos, Bohm (2005) sugere que a forma de se dialogar sem agenda ou líder é começar conversando sobre a ansiedade gerada por tais condições. Além disso, indica que pode existir um facilitador do diálogo, o qual deve ter o cuidado para se retirar da função assim que possível para deixar que o grupo ande sozinho.

Há também a importância da ausência de decisão no diálogo. "Num grupo de diálogo, não decidimos o que fazer a respeito de nada. Isso é crucial" (BOHM, 2005, p. 50). Ao agir dessa forma, a liberdade estará instaurada. Outro ponto tratado pelo autor é o impulso da necessidade. Ele afirma que, ao estabelecer algo como uma necessidade absoluta, aquilo que é inegociável, o conflito surge, pois há o encontro com outra necessidade absoluta de outro indivíduo ou grupo, podendo impedir ou permitir a ocorrência do diálogo dependendo da postura adotada pelos participantes. Caso não permitam o questionamento de tal necessidade, ele estará impedido; por outro lado, se houver abertura para o questionamento, ele ocorrerá, permitindo que ao fazê-lo se possa entrar num estado coerente de ideias.

Isaacs (1999) utiliza das ideias de David Kantor e William Lehr (1975) para apontar outros dois aspectos importantes. O primeiro se refere à identificação das linguagens utilizadas pelas pessoas. Afirma que existem três tipos de linguagem: a do afeto, em que as pessoas falam o que sentem e investigam como os outros se sentem; a do significado, em que se busca compreender as ideias, os valores e as crenças naquilo que se conversa; e a da ação, na qual se quer saber como as coisas serão feitas. Se as pessoas estiverem numa conversa usando linguagens diferentes elas não se entenderão e, por isso, "entender qual linguagem você e os outros estão falando é vital para se engajar num diálogo genuíno" (ISAACS, 1999, p. 211, tradução nossa).

Pessoas falando a linguagem do sentimento tendem a ser desconsideradas pelas pessoas que falam a linguagem da ação e do poder. Pedir para que estas pessoas [da ação] reflitam sobre o significado das coisas pode muitas vezes evocar uma reação de que você está sendo muito 'intelectual'. E fazer perguntas sobre como agir pode parecer prematuro para aqueles que falam as línguas do sentimento ou do significado. (ISAACS, 1999, p. 211, tradução nossa).

O segundo aspecto é a identificação dos sistemas paradigmáticos adotados pelas pessoas. Afirma que existem três tipos de sistema: o aberto, que funciona a partir da participação de todos, objetivando equilibrar as necessidades individuais e coletivas; o fechado que coloca a comunidade e as tradições históricas em primeiro lugar e os indivíduos em segundo; e o randômico, que às vezes funciona como um sistema aberto e às vezes como um sistema fechado (ISAACS, 1999).

Todos esses aspectos devem ser trabalhados no grupo de maneira processual, entendendo que a dinâmica de participação e envolvimento no diálogo leva tempo e, portanto, não é imediata. Nesse sentido, Isaacs $(1993,1999)$ apresenta os estágios do diálogo (Figura 2), mostrando a evolução do contêiner para acolher os diferentes momentos, uma vez que 
possui "diferentes qualidades de pressão, energia e conhecimento" (ISAACS, 1999, p. 255, tradução nossa) que emergem a partir do surgimento de crises.

Figura 2 - Estágios do diálogo

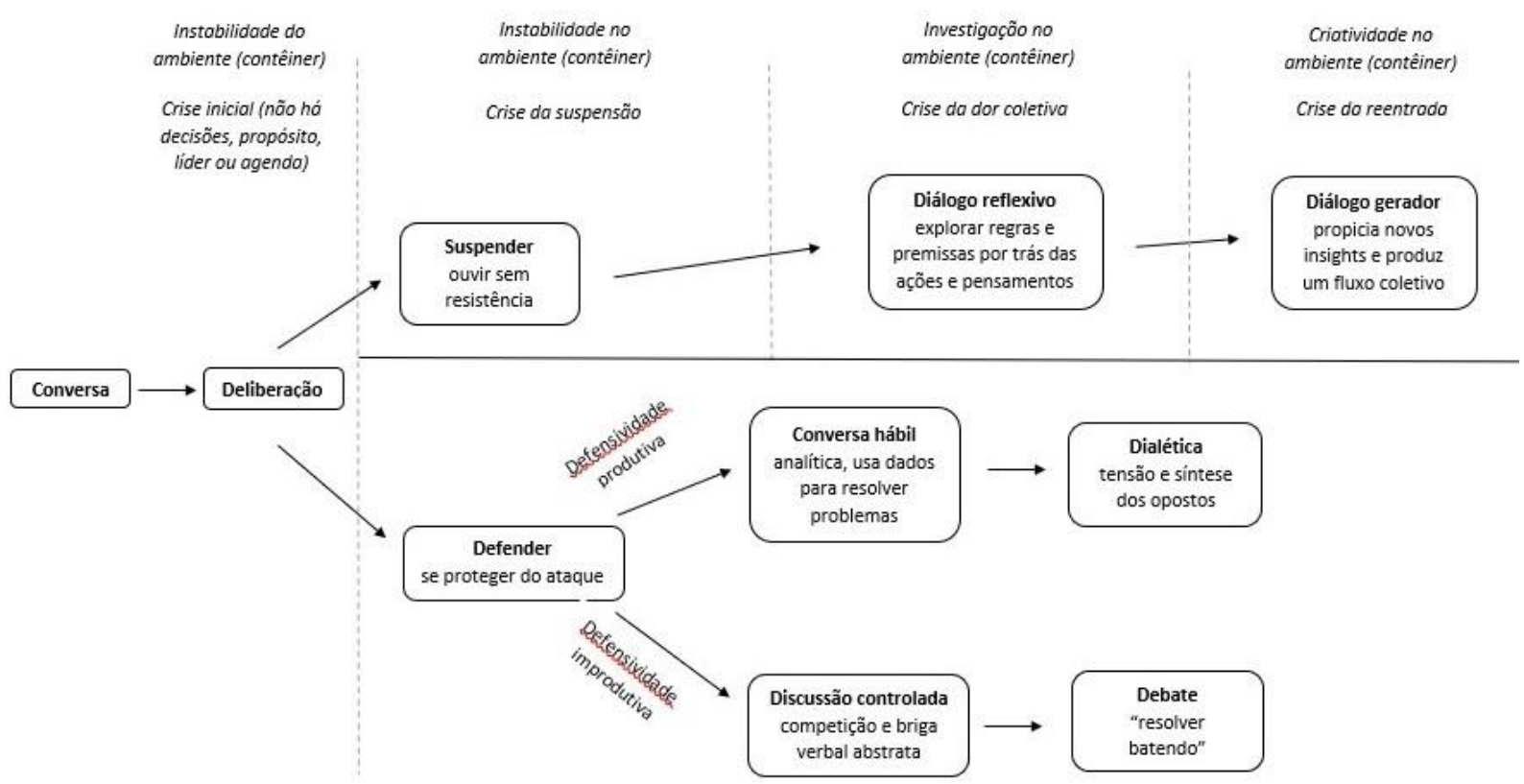

Fonte: Adaptado e traduzido de Isaacs $(1993,1999)$.

O processo dialógico se inicia com a deliberação das pessoas em estabelecer um diálogo no grupo. Nos primeiros encontros, os participantes adotam muitas regras de como se comportar, formas de pensar e agir que já têm familiaridade (preestabelecidas) e, portanto, que se sentem confortáveis. Assim, o contêiner apresenta um clima de polidez, no qual as pessoas evitam contradizer umas às outras e entrar em qualquer tipo de conflito. O sentimento que prevalece é o medo, o qual "parece reforçar o comportamento de seguir regras [preestabelecidas]" (ISAACS, 1999, p. 261, tradução nossa). Surge então a primeira crise, na qual as pessoas percebem a dificuldade de se alterar o modo habitual de conversar, expondo as opiniões para que os outros a observem sem julgamentos; e, como tal postura não pode ser imposta, surge o sentimento de frustração entre os participantes (ISAACS, 1993).

Com o caminhar do processo, gradualmente as pessoas passam a dizer o que pensam e começa a surgir a fragmentação. Aqui, as "pessoas começam a batalhar para saber qual significado/ponto de vista tem mais poder" (ISAACS, 1999, p. 265, tradução nossa), de forma que o sentimento que prevalece é o da raiva, caracterizado pelo pensamento de que "não apenas nós temos posições diferentes, como claramente a sua é errada e a culpada pelas dificuldades que estamos enfrentando" (ISAACS, 1999, p. 269, tradução nossa). O autor afirma que muitas pessoas não conseguem passar desse estágio e acabam retornando para a polidez.

Instaurada essa polarização, entendida como algo positivo e esperado para a evolução do diálogo, as pessoas se deparam com uma importante escolha: defender ou suspender suas opiniões. Tal escolha acarreta uma nova crise, a da suspensão. Isso ocorre porque apesar da boa vontade em escolher suspender as opiniões, haverá momentos que o hábito de defendê-las ressurgirá, e, portanto, os participantes ficam desorientados (ISAACS, 1993).

Se as pessoas se mantiverem no processo para além desse ponto, a conversa começa a fluir de uma nova forma e o ambiente passa a ser de investigação, instaurando o diálogo 
reflexivo. As pessoas passam a investigar juntas os pensamentos e sentimentos, tornando-se mais sensíveis à forma como a conversa afeta o grupo, de forma que insights começam a surgir (ISAACS, 1993). Nesse estágio "as pessoas não sentem obrigação de exigir dos outros resposta ou concordância com suas perspectivas. [...] Embora eu possa ter uma posição, eu também sou uma pessoa com uma história, uma experiência particular" (ISAACS, 1999, p. 273, tradução nossa).

Decorrente desse processo surge a crise da dor coletiva, caracterizada pela tomada de consciência das pessoas do impacto que o modo fragmentado do pensamento ocasionou em suas vidas. Essa dor surge da perda de crenças que sustentavam a existência de cada indivíduo de um lado e do exercício de trabalhar novas relações emocionais e cognitivas de outro. É nesse momento, proporcionado por esta crise, que é possível transformar as formas de relação, uma vez que as maneiras de pensar e agir que impedem a união se tornam evidentes (ISAACS, 1993).

Se essa crise é superada, um novo estágio de consciência se abre e instaura-se o diálogo gerador. Aqui a atmosfera se caracteriza por "acomodar radicalmente diferentes pontos de vista sem exigir que nenhum deles mude" (ISAACS, 1999, p. 280, tradução nossa). Aqui as pessoas não reagem, elas ouvem e "conectam o que está acontecendo na conversa com o que está acontecendo com elas próprias" (ISAACS, 1999, p. 282, tradução nossa), percebendo que compartilham um significado comum por terem explorado os pressupostos de todos os envolvidos no processo, instaurando um ambiente de criatividade (ISAACS, 1993).

Após esse momento, surge a crise da reentrada. Depois de viver um processo desse, há a dificuldade de ter que voltar para as relações habituais, de voltar para o mundo. "Essa crise envolve aprender a deixar o significado do antigo mundo familiar mudar" (ISAACS, 1999, p. 286, tradução nossa).

Dessa forma, Bohm (2005) acredita que o diálogo é o caminho para a mudança do mundo, inclusive para os problemas ambientais. Afirma que "temos de compartilhar nossa consciência e nos capacitarmos para pensar juntos [...]. Se enfrentarmos o que ocorre num grupo de diálogo, compreenderemos o núcleo do que acontece no todo da sociedade" (p. 47).

\subsubsection{Círculos de cultura}

Paulo Freire (1921-1997), educador e pensador brasileiro, atual patrono da educação brasileira (BRASIL, 2012), apresenta o diálogo como caminho possível para a superação da relação opressor-oprimido, na qual o primeiro se caracteriza por ter força e poder, utilizados na dominação do segundo que, por sua vez, vive aderido a uma realidade mitificada. A superação dessa relação e a consequente libertação dos oprimidos se dão a partir da "compreensão crítica da totalidade em que estão" (FREIRE, 1981, p. 113), desvelando as condições histórico-culturais por meio dos círculos de cultura (FREIRE, 1981).

Antes de explorarmos esse caminho metodológico, o qual se constitui enquanto uma Ação Dialógica marcada pela co-laboração, união, organização e síntese cultural, é preciso entender os princípios dialógicos que o guiam. Freire (1981) fala de seis valores fundamentais do diálogo: amor, humildade, fé, confiança, esperança e pensar crítico.

Por ser o diálogo um encontro que permite a constante afirmação e desenvolvimento da humanização, assim como um ato de criação e recriação, constitui-se enquanto um ato amoroso (FREIRE, 1981). "Não há diálogo [...] se não há um profundo amor ao mundo e aos homens" (FREIRE, 1981, p. 93). Por ser um ato amoroso, o diálogo não pode se dar na relação de dominação.

Freire (1981) afirma que também não há diálogo sem humildade. Ao existir arrogância no encontro entre homens e mulheres, ou seja, uns se sentindo superiores aos outros, não é possível a relação dialógica. "Como posso dialogar, se alieno a ignorância, isto é, se a vejo 
sempre no outro, nunca em mim?" (FREIRE, 1981, p. 95). Ao se achar mais sabedor do que o Outro, pensa ser o único contribuinte da conversa e não se considera o saber alheio. "Neste lugar de encontro, não há ignorantes absolutos, nem sábios absolutos: há homens que, em comunhão, buscam saber mais" (FREIRE, 1981, p. 95).

Outra característica importante é a fé nos homens. "Fé no seu poder de fazer e de refazer. De criar e recriar. Fé na sua vocação de Ser Mais, que não é privilégio de alguns eleitos, mas direito dos homens" (FREIRE, 1981, p. 95). E essa fé deve existir antes mesmo da ocorrência do diálogo. "O homem dialógico tem fé nos homens antes de encontrar-se frente a frente com eles" (FREIRE, 1981, p. 95).

Ao se estabelecer o amor, a humildade e a fé num encontro entre homens e mulheres, a confiança se faz consequência natural. Esta se instaura no momento do diálogo (FREIRE, 1981). "A confiança vai fazendo os sujeitos dialógicos cada vez mais companheiros na pronúncia do mundo. Se falha esta confiança, é que falharam as condições discutidas anteriormente" (FREIRE, 1981, p. 96, grifo do autor). Ela se traduz no testemunho que um indivíduo dá aos outros participantes do encontro dialógico sobre seus reais pensamentos e intenções (FREIRE, 1981).

O diálogo também deve vir acompanhado da esperança. Homens e mulheres reunidos num encontro para pronunciar o mundo, mediatizados por ele, para sua conquista, não podem fazê-lo sem ter um objetivo, sem nada esperar (FREIRE, 1981). "Se os sujeitos do diálogo nada esperam do seu quefazer já não pode haver diálogo. O seu encontro é vazio e estéril. É burocrático e fastidioso" (FREIRE, 1981, p. 97). Por último, não é possível o diálogo sem um pensar crítico, o qual permite o desvelamento da realidade entendendo-a enquanto processo histórico e que, por isto mesmo, pode ser alterada, transformada (FREIRE, 1981).

Baseado nesses valores, Freire (1981) elaborou a Teoria da Ação Dialógica, caracterizada por quatro elementos: a co-laboração; a união; a organização; e a síntese cultural. A co-laboração se caracteriza pelo encontro de homens e mulheres, para juntos, transformar a realidade. Esta é problematizada, e não mitificada. Aqui não há relação de dominação. Esse trabalho conjunto se dá por meio da comunicação, uma vez que "o diálogo, que é sempre comunicação, funda a colaboração" (FREIRE, 1981, p. 197). Seu elemento oposto, característico da Ação Antidialógica, é a conquista. Esta é marcada por uma relação de dominação de um indivíduo pelo outro, na qual o dominado se torna um objeto, tendo sua humanidade roubada. O objetivo dessa conquista é manter a realidade tal qual ela se apresenta, ou seja, o cenário no qual os indivíduos conquistadores e opressores possuem o poder. E para manter essa realidade, se utilizam dos mitos, os quais permitem a criação de um mundo falso, a-histórico, por meio dos "comunicados" que são aceitos sem reflexão pelos conquistados, uma vez que se encontram alienados da realidade (FREIRE, 1981).

O segundo elemento da Teoria da Ação Dialógica é a união, a qual busca aproximar os indivíduos. Para sua ocorrência, é essencial que se desmitifique a realidade, pois assim permite que "reconhecendo o porque e o como de sua 'aderência', exerçam um ato de adesão à práxis verdadeira de transformação da realidade injusta" (FREIRE, 1981, p. 205, grifo do autor). Seu elemento oposto é a divisão dos conquistados, caracterizando-se pelo constante exercício de impedir que a maioria dominada se una e se organize, haja visto que ao fazê-lo contestarão a organização social vigente e, assim, os conquistadores terão seu poder ameaçado (FREIRE, 1981).

Outro elemento da Ação Dialógica é a organização das massas. Para explicá-la se faz necessário entender o importante papel da liderança revolucionária, que se caracteriza pela postura dialógica. Portanto, a liderança, para co-laborar com as massas, deve estar em comunhão com elas, estabelecer uma relação de confiança para juntas desvelar a realidade, desmitificando-a e, assim, transformá-la. Seu papel é o de dar o testemunho de que a busca por libertação é um objetivo comum, ou seja, a libertação é o motivo pelo qual a organização 
se dá. No entanto, não pode dar seu testemunho de forma impositiva, mas deve fazê-lo com o povo (FREIRE, 1981). Seu elemento oposto é a manipulação que objetiva impedir que os conquistados desenvolvam o pensamento crítico. Para isso, utilizam da imaturidade política e de mitos para convencer as massas que os objetivos dos conquistadores são válidos e devem ser defendidos, já que eles se apresentam, falsamente, como os protetores da sociedade. Essa estratégia é muito forte, uma vez que o conquistado, hospedando dentro de si o conquistador, passa a acreditar que a realidade que se apresenta é imutável e não deve ser contestada (FREIRE, 1981).

O último elemento da Teoria da Ação Dialógica é a síntese cultural. Nela não há imposição de uma visão de mundo, mas sim o respeito às diferentes formas de ver a realidade. O objetivo é incidir sobre ela a partir dessas diferentes formas de vê-la. Ou seja, é a ação pela qual homens e mulheres podem se libertar da alienação, a partir do entendimento histórico de sua condição. A liderança aqui não impõe seus valores, mas se junta ao povo para que unidos e organizados possam se libertar (FREIRE, 1981). "A síntese cultural não nega as diferenças entre uma visão e outra, pelo contrário, se funda nelas. $\mathrm{O}$ que ela nega é a invasão de uma pela outra. O que ela afirma é o indiscutível aporte que uma dá à outra" (FREIRE, 1981, p. 215). Nesse sentido, há uma estreita relação com o diálogo gerador proposto por Isaacs (1993, 1999), no qual não se tenta convencer o Outro ou impor ideias, reconhecendo que cada um tem uma história diferente. Seu elemento oposto é a invasão cultural, caracterizada pela imposição da visão de mundo dos conquistadores aos conquistados. Para que essa imposição seja "aceita" pela massa se faz necessária uma condição básica: o convencimento de que os conquistados são inferiores aos conquistadores (FREIRE, 1981).

Considerando o exposto acima, Freire (1981) apresenta os círculos de cultura como o processo pelo qual os participantes agem dialogicamente, desvelando a realidade que vivem, identificando e entendendo suas contradições fundamentais como construções históricoculturais que podem ser transformadas.

Da mesma forma que os grupos de diálogo de Bohm e Isaacs possuem um procedimento metodológico central, a suspensão dos pressupostos, os círculos de cultura apresentam o exercício de codificação e descodificação, sendo a primeira a representação de uma situação existencial e a segunda a análise crítica de tal situação. Dessa forma, a codificação é a representação do todo e a descodificação "implica numa ida das partes ao todo e numa volta deste às partes, que implica num reconhecimento do sujeito no objeto (a situação existencial concreta) e do objeto como situação em que está o sujeito" (FREIRE, 1981, p. 114).

O processo de descodificação é detalhado por Freire (1983), constituindo-se por quatro momentos. O primeiro se caracteriza pela observação/“ad-miração" da realidade codificada com o intuito de apreendê-la como um todo. O segundo, pela descrição de tal realidade, cindindo a totalidade "ad-mirada" em partes a serem analisadas. Em seguida, no terceiro momento, há a "re-admiração" das "ad-mirações" anteriores sobre a realidade codificada, vista novamente em sua totalidade, uma vez que se busca identificar as relações existentes entre os elementos desta, de forma que, ao fazê-lo, as pessoas passam a questionar as opiniões construídas ao longo de suas vidas sobre a situação existencial representada, desenvolvendo, assim, uma criticidade que não mais aceita explicações focalistas da realidade, ou seja, sua compreensão fragmentada. A partir disso, emerge o quarto momento caracterizado pelo aprofundamento e realização da análise crítica do contexto em que se vive.

Os círculos de cultura são constituídos por três fases. A primeira se inicia com a visita dos investigadores (ou propositores do processo dialógico) ao local escolhido para o trabalho, apresentando a proposta para as pessoas que ali vivem e convidando-as para participar do processo de investigação temática. Depois de formada a equipe de investigação com pessoas interessadas da comunidade, são realizadas visitas ao local, que se apresenta como uma 
"codificação viva", a partir da qual os investigadores realizarão o exercício de descodificação, anotando em seus diários de campo tudo o que chama a atenção: modos de relacionamento das pessoas entre si e com o ambiente, os costumes, a fala e o que mais for relevante. Essas visitas devem ocorrer em diferentes horários e dias para que os investigadores possam ter uma compreensão profunda das diferentes dinâmicas daquela realidade (FREIRE, 1981).

Findadas as primeiras visitas, constroem-se relatórios com as diversas percepções dos investigadores que devem ser dialogadas entre eles em seminário. O objetivo desse diálogo é permitir aos participantes que percebam e analisem suas percepções a partir da escuta das percepções dos outros, ou seja, que "re-admirem" "sua admiração anterior no relato da 'admiração' dos demais" (FREIRE, 1981, p. 124). O processo de "re-admirar" a admiração por meio da "ad-miração" do Outro permite retotalizar a realidade cindida, que se apresentará de uma nova forma, a qual exigirá nova descodificação e seminário avaliativo para "re-admirar" o que se admirou (FREIRE, 1981).

A partir desse exercício, os investigadores conseguem identificar as principais contradições existentes naquela realidade, que envolvem as "situações-limites". Do conjunto de contradições identificadas serão escolhidas algumas para se formar as codificações "que vão servir à investigação temática" (FREIRE, 1981, p. 127) junto às pessoas do local de trabalho, com o propósito de identificar a percepção que possuem sobre tais contradições, caracterizando a segunda fase do processo. Essas codificações podem ser representadas por pinturas, fotos, dramatizações, áudios, vídeos ou até mesmo pela fala. É importante ressaltar que é preciso que os sujeitos reconheçam a situação codificada (realidade conhecida) e que as codificações não sejam tão explícitas e nem tão enigmáticas (FREIRE, 1981).

Preparadas as codificações, inicia-se a terceira fase. Nela, os investigadores voltam à área para dialogar nos "círculos de investigação temática", nos quais "os participantes [...] vão extrojetando, pela força catártica da metodologia, uma série de sentimentos, de opiniões, de si, do mundo e dos outros, que possivelmente não extrojetariam em circunstanciais diferentes" (FREIRE, 1981, p. 132-133). Freire diz que cada círculo de investigação temática deve ter um máximo de vinte pessoas, "existindo tantos círculos quantos a soma de seus participantes atinja a da população da área ou da subárea em estudo" (FREIRE, 1981, p. 132).

Depois de realizadas as descodificações nos círculos de investigação temática, os investigadores analisam os resultados coletados, os temas geradores que emergiram. Destes é feita a delimitação temática da qual se desprenderá um projeto de "redução" temática com o objetivo de reduzir um ou mais temas em seus núcleos fundamentais. Além disso, "neste esforço de 'redução' da temática significativa, a equipe reconhecerá a necessidade de colocar alguns temas fundamentais que, não obstante, não foram sugeridos pelo povo, quando da investigação" (FREIRE, 1981, p. 136).

Findada a redução, é realizada uma nova codificação da realidade, compondo o conteúdo programático do processo educador a ser utilizado junto às pessoas da área de trabalho nos chamados círculos de cultura. Nestes as pessoas se constituem enquanto sujeitos que desvelam a totalidade em que estão inseridas por meio também da codificação e descodificação dialógica (FREIRE, 1981).

Por fim, Freire afirma que caso não seja viável realizar todo o processo de investigação temática proposto, é possível

Com um mínimo de conhecimento da realidade [...] escolher alguns temas básicos que funcionariam como "codificações da investigação". Começariam assim o plano com temas introdutórios ao mesmo tempo em que iniciariam a investigação temática para o desdobramento do programa, a partir destes temas. (FREIRE, 1981, p. 139).

\section{Síntese dos caminhos metodológicos e perguntas-indicadoras}


A relação entre as ideias dos autores do diálogo, entendendo seus diferentes contextos e perspectivas, constitui-se num importante exercício para a emergência de novas compreensões sobre o assunto. Permite, como sugerem Aragão e Navarro (2004, p. 115), a descoberta de "ângulos que continuam ocultos à espera de um dia serem descobertos/acordados/construídos por outros olhares, que poderão vir de lugares/tempos distantes".

Stewart, Zediker e Black (2004), realizando esse exercício de síntese, enunciaram que Buber, Bohm e Freire escreveram sobre o diálogo a partir de bases experienciais e hábitos mentais que apresentam mais similaridades do que diferenças, mesmo que o tenham feito em tempos e culturas diferentes. As bases experienciais se constituem pelos eventos vividos por esses autores ao longo de suas trajetórias históricas, contribuindo para a formulação de suas ideias. De acordo com os autores

David Bohm "teve uma infầncia difícil" (Pruyn, 2000), não somente porque ele era um judeu que vivia nos Estados Unidos, mas também por causa da doença mental de sua mãe. Depois de um começo promissor como intelectual (Caltech, Berkeley, uma nomeação em física em Princeton), foi levado ao exílio pelo macarthismo e, apesar de sua amizade com Einstein, foi ignorado ou ridicularizado por muitos colegas por seu misticismo. Os pais de Buber se divorciaram, sua precocidade o fez "estranho" quando criança, ele foi expulso de sua casa austríaca pelos nazistas e viveu em contínuo conflito com líderes xenófobos e anti-árabes em Israel (Friedman, 1981, 1983b, 1983c Gordon, 1988). Quanto a Freire, a quebra do mercado de 1929 significou que "a precária estabilidade da família de classe média de Freire cedeu e ele se viu compartilhando a situação dos 'miseráveis da terra'. Isso teve uma influência profunda em sua vida quando ele conheceu as angustiantes dores da fome" (Shaull, 1990, p. 10). Freire dedicou sua vida a uma filosofia da educação que respondia à crise existencial que ele experimentou e viu diante dele (STEWART; ZEDIKER; BLACK, 2004, p. 30, tradução nossa)

Os hábitos mentais, por sua vez, caracterizam-se pela forma de pensar tais eventos. Há dois hábitos mentais marcantes nos autores do diálogo. O primeiro é o holismo, a busca por compreender a realidade considerando sua totalidade; e o segundo é a tensionalidade, a qual se constitui enquanto uma característica do pensamento holístico, buscando entender a realidade de forma dinâmica e dialética (STEWART; ZEDIKER; BLACK, 2004).

Em sua tese de doutorado, Navarro (2005) propõe um caminho dialógico a partir de uma síntese das ideias de David Bohm, Paulo Freire e Mikhail Bakhtin sobre o diálogo, partindo do pressuposto de que esses autores compartilham a importância de se ter "ciência da dialogia como fundamento da vida" (p. 36), mas que apresentam caminhos diferentes para alcançá-la.

Sua proposta dialógica se inicia com a realização da suspensão dos pressupostos (perspectiva bohmiana), o qual permite, por sua vez, o processo de conscientização a respeito da construção histórico-cultural que se vive (perspectiva freireana), culminando, por fim, no aprendizado de que é na relação com o outro que está o sentido da existência (perspectiva bakhtiniana) (NAVARRO, 2005).

Andrade (2013), por sua vez, utiliza em sua tese diversos autores do diálogo para construir seu entendimento sobre o assunto. Dentre as reflexões tecidas propõe uma síntese entre as ideias de David Bohm, William Isaacs e Paulo Freire sobre a dimensão do agir em busca de transformações na realidade, afirmando que

a suspensão de pressupostos de Bohm [...] [pode] promover importantes mudanças nos sentidos que as pessoas atribuem ao mundo (BOHM, 1999), repercutindo, consequentemente, em suas ações. Assim, como coloca Isaacs (1999a), a prática do diálogo não visa apenas à conversa, mas também a ação, e especificamente a ação coletiva. O diálogo é, portanto, uma práxis, em que o encontro dos homens promove a transformação do mundo, "um caminho pelo qual os homens ganham significação enquanto homens" (FREIRE, 1987, p. 45). (ANDRADE, 2013, p. 62-63). 
Com o exposto acima, buscou-se realizar também um exercício de síntese a partir das ideias de David Bohm, William Isaacs e Paulo Freire por se entender que a união dos princípios e características presentes nos grupos de diálogo e nos círculos de cultura pode potencializar a caminhada pela espiral dialógica. Assim, os elementos presentes nos caminhos propostos pelos autores foram organizados em duas categorias, cada qual composta por um conjunto de perguntas-indicadoras, que podem subsidiar o desenvolvimento, execução e avaliação de processos de EA. Vale destacar que essa compreensão é um avanço daquela apresentada na dissertação de mestrado do primeiro autor (MONTEIRO, 2018), a qual dividia os elementos em três categorias e a partir das quais se realizou aqui a junção de duas delas.

A primeira, intitulada "Aspectos Externos", é composta pelos elementos referentes à estrutura do encontro: sua frequência; o número de pessoas envolvidas; sua disposição; e o local do encontro. A segunda categoria, intitulada "Aspectos Internos", traz os elementos ligados às posturas mentais e emocionais de cada indivíduo, assim como às posturas metodológicas das(os) educadoras ambientais: a deliberação pelo diálogo; a realização da investigação temática; a realização dos círculos de investigação temática; a realização dos círculos de cultura; ouvir e ser ouvido; enfrentar conflitos; demonstrar amor, humildade, fé, confiança, esperança e pensamento crítico; a realização dos quatro momentos do procedimento metodológico proposto aqui e apresentado nos próximos parágrafos; o desvelamento de aspectos culturais; e a existência de tomadas de decisão conjuntas que se desdobram em um trabalho colaborativo, organizado e que acolhe as diferenças. As perguntas-indicadoras referentes a cada categoria estão descritas no Quadro 1. 
Quadro 1 - Indicadores do diálogo

\begin{tabular}{|c|c|}
\hline ESPIRAL DIALÓGICA & PERGUNTAS-INDICADORAS \\
\hline \multirow{4}{*}{ Aspectos Externos } & Qual é a frequência dos encontros? \\
\hline & Qual é o número de pessoas envolvidas nos encontros? \\
\hline & $\begin{array}{l}\text { Qual é a disposição das pessoas nos encontros (em circulo, em } \\
\text { fileira etc.)? }\end{array}$ \\
\hline & $\begin{array}{l}\text { Os locais dos encontros possuem uma boa acústica e propicia } \\
\text { que os atores estejam focados? }\end{array}$ \\
\hline \multirow{9}{*}{ Aspectos Internos } & Há deliberação pelo diálogo? \\
\hline & $\begin{array}{l}\text { Há o convite para os possiveis participantes do processo } \\
\text { realizarem as primeiras etapas da investigação temática? }\end{array}$ \\
\hline & $\begin{array}{l}\text { Há indicios da ocorrência de uma investigação temática } \\
\text { conjunta? Se desdobram em circulos de investigação temática? } \\
\text { Se sim, estes resultam em circulos de cultura? Caso o processo } \\
\text { completo não tenha ocorrido, pelo menos realizou-se a } \\
\text { perspectiva reduzida proposta por Freire? }\end{array}$ \\
\hline & $\begin{array}{l}\text { Todos podem se expressar, respeitando e ouvindo, por sua vez, } \\
\text { os outros? }\end{array}$ \\
\hline & Permite-se a emergência da polarização por meio dos conflitos? \\
\hline & $\begin{array}{l}\text { Há indicios da presença do amor, da humildade, da fé, da } \\
\text { confiança, da esperança e do pensar critico no processo vivido? }\end{array}$ \\
\hline & $\begin{array}{l}\text { Há indicios da ocorrência dos quatro momentos do procedimento } \\
\text { metodologico proposto aqui: (1) codificação; (2) observação da } \\
\text { codificação ou escuta genuina; (3) descrição da codificação; (4) } \\
\text { "re-admiração" das admirações, observando emoções? }\end{array}$ \\
\hline & $\begin{array}{c}\text { Há indicios de que o processo vivido permite o desvelamento de } \\
\text { aspectos culturais? }\end{array}$ \\
\hline & $\begin{array}{l}\text { Existem tomadas de decisão conjuntas entre os atores que se } \\
\text { desdobram em trabalhos colaborativos, organizados e que } \\
\text { acolhem as diferenças, a partir do desvelamento da realidade por } \\
\text { meio dos temas geradores? }\end{array}$ \\
\hline
\end{tabular}

Fonte: Elaboração própria, apoiada em: Freire (1981, 1983), Isaacs (1993, 1999), Bohm (2005), Andrade (2013) e Monteiro (2018).

Além disso, sugere-se aqui um processo metodológico caracterizado pela união dos procedimentos de codificação e descodificação, propostos por Freire $(1981,1983)$ e de suspensão dos pressupostos, indicado por Bohm (2005) e Isaacs (1999). A síntese dos procedimentos proposta aqui tem na codificação o primeiro momento do processo, uma vez que permite a representação de uma situação existencial vivida na realidade concreta. A partir disso, pode-se partir tanto para a descodificação, quanto para a suspensão.

Realizando o exercício de comparação entre esses dois procedimentos foi possível perceber que ambos propõem processos parecidos. A descodificação é composta pelos quatro 
momentos sugeridos por Freire (1983): observação da codificação; descrição; "re-admiração" das admirações anteriores; e análise crítica. A suspensão dos pressupostos, por sua vez, pode ser entendida por três momentos a partir do que apresentam Bohm (2005) e Isaacs (1999): a escuta genuína, que pode ser compreendida enquanto um paralelo à observação sugerida por Freire; a disponibilização para si e para os outros sobre o que se pensa a respeito da codificação em questão, constituindo-se enquanto um paralelo à descrição de Freire; o entendimento do processo pelo qual tal forma de pensar se constituiu, observando as sensações corporais e emoções que surgem quando nos deparamos com pressupostos similares ou antagônicos aos nossos, o que nos parece se aproximar do exercício de "readmirar" as admirações anteriores e do aprofundamento da análise crítica, inclusive oferecendo a esta mais elementos, a partir da observação das sensações e emoções, para efetivamente ser crítica.

Dessa forma, o procedimento metodológico que se propõe aqui é composto por quatro momentos: (1) codificação; (2) observação da codificação ou escuta genuína; (3) descrição da codificação; (4) "re-admiração" das admirações, observando as sensações corporais e emoções e analisando criticamente todo o processo. Esses momentos compõem um ciclo virtuoso (Figura 3) que permite a emergência da criticidade e conscientização (freireana) e do pensamento coletivo e coerente (bohmiano), culminando no incremento de uma existência dialógica (buberiana).

Figura 3 - Os quatro momentos do procedimento metodológico
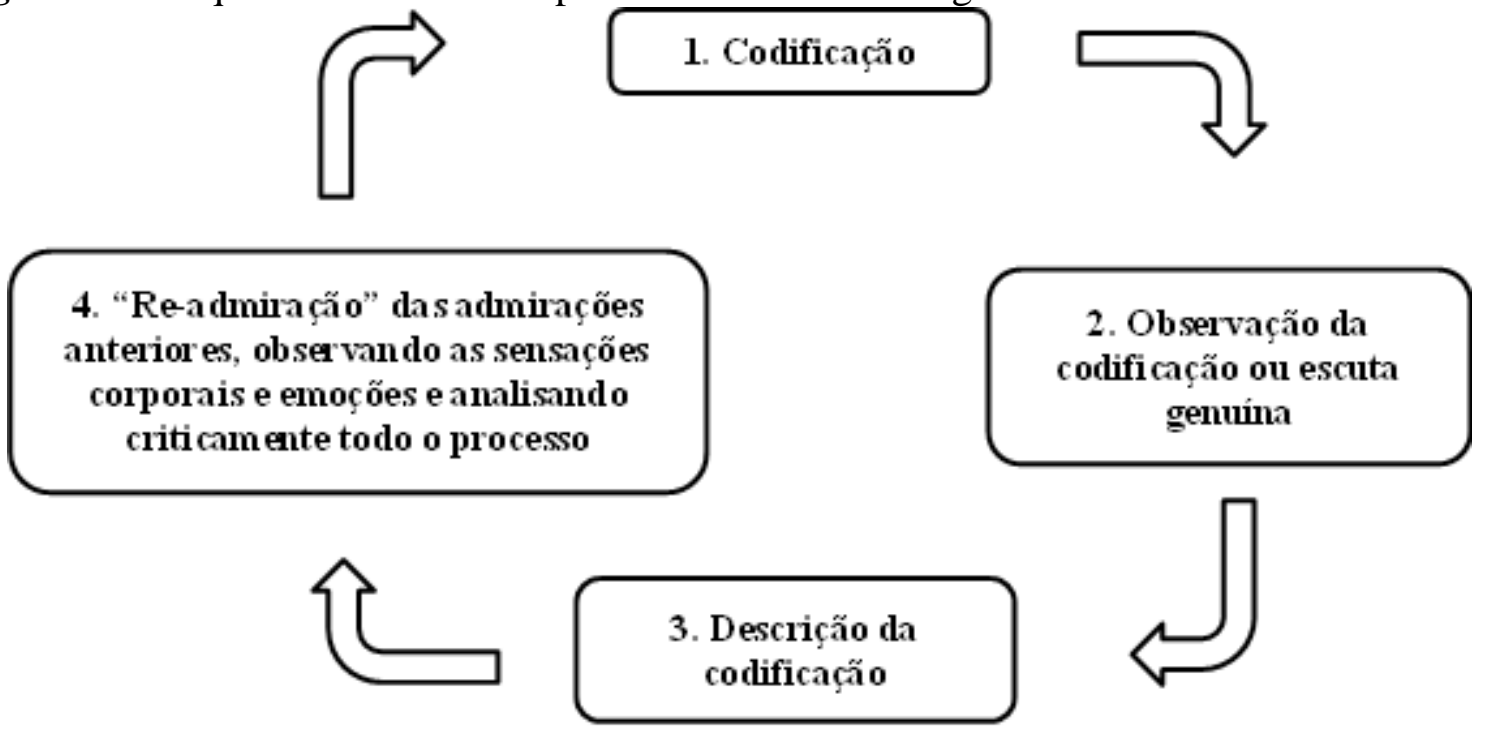

Fonte: Elaboração própria.

Por exemplo, no diálogo entre uma ONG, ou qualquer outra agência que objetive promover transformações por meio de processos educadores em determinada realidade, e um coletivo de pescadores, ou qualquer outro coletivo de agentes de transformação de determinada realidade, o primeiro momento é o da codificação da realidade, a qual deverá apresentar as situações vividas pelos sujeitos que participam do diálogo e suas possíveis contradições.

Essa codificação pode ser feita previamente ao encontro, realizando um levantamento das situações vividas e suas possíveis contradições, sendo apresentada por meio de uma fotografia, um vídeo ou uma poesia, por exemplo. Ou pode ser feita durante o encontro a partir de testemunhos de um ou vários participantes, a partir dos quais vão emergindo as contradições. 
À medida que a codificação é exposta, faz-se necessário observá-la e/ou escutá-la, a depender do instrumento utilizado, de forma genuína, exercitando a presença e atenção no encontro, caracterizando o segundo momento. De posse dessa presença em que se identifica a realidade codificada, começa-se o terceiro momento, a descrição. Cada participante terá a possibilidade de disponibilizar para si e para os outros o que pensa sobre o que se apresenta codificado e, por existir diferentes trajetórias de vida, emergirão leituras da realidade baseadas em diferentes pressupostos.

É a partir do enfrentamento dos conflitos entre pressupostos e do contato e da abertura ao diferente que se abrirá a oportunidade de "re-admirar" as admirações anteriores, observando as sensações corporais e emoções e analisando criticamente todo o processo, constituindo o quarto momento. Aqui se busca rever as formas de pensar e agir, a partir de diversos questionamentos: por que penso da forma que penso sobre esse assunto? De onde veio essa forma de ver tal aspecto da vida? Com quem e em que contexto adquiri essa visão? Desde quando penso dessa forma? O que sinto (sensações corporais e emoções) quando escuto a defesa de algo que abomino? Por que abomino esse algo? Será que realmente é abominável? O que sinto (sensações corporais e emoções) quando escuto algo que acredito e concordo? Será que esse algo é realmente verdadeiro? Etc.

Esse processo de autorreflexão, oportunizado pelo encontro de diferentes formas de viver a vida, se apresenta enquanto uma oportunidade de se criar um pensamento crítico, coerente e coletivo, no qual a união, a solidariedade, o cuidado com o Outro, o sentimento de pertença e responsabilidade emergem, permitindo a ação conjunta em prol da transformação das contradições histórico-culturais vividas.

\section{Considerações finais}

Buscamos aqui contribuir para o aprofundamento da compressão sobre o diálogo, importante princípio e objetivo da educação ambiental, apresentando uma síntese na qual partimos da concepção de Martin Buber, em que pudemos conceber a ideia de uma espiral dialógica composta por diversos caminhos, os quais podem permitir o incremento de uma existência pautada por tal qualidade.

Apresentamos dois caminhos possíveis, os grupos de diálogo de David Bohm, também estudados por William Isaacs, e os círculos de cultura de Paulo Freire, sugerindo a união dos elementos presentes neles em duas categorias, compostas por perguntas-indicadoras que possam subsidiar o desenvolvimento, execução e avaliação de processos de educação ambiental. Além disso, elaborou-se um procedimento metodológico, caracterizado por quatro momentos, que possibilita a criticidade e conscientização freireana e o pensamento coletivo e coerente bohmiano.

Por outro lado, existem ainda outros caminhos a serem explorados. Há autores, não considerados aqui, que estudaram o diálogo, como Hans-Georg Gadamer, Jürgen Habermas, Mikhail Bakhtin e outros. Assim, faz-se necessário o desenvolvimento de novas pesquisas que busquem aprofundar os caminhos dialógicos existentes e desvendar novos, alimentando inclusive as categorias elaboradas e sugeridas neste artigo para que nós, educadoras(es) ambientais, possamos estar constantemente aprimorando nossos processos educadores com o objetivo de promover a experiência de relações dialógicas. 


\section{Referências}

ANDRADE, D. F.; LUCA, A. Q.; SORRENTINO, M. O diálogo em processos de políticas públicas de educação ambiental no Brasil. Educação e Sociedade, Campinas, v. 33, n. 119, p. 613-630, 2012.

ANDRADE, D. F. O lugar do diálogo nas políticas públicas de educação ambiental. Tese (Doutorado em Ciência Ambiental) - Universidade de São Paulo, São Paulo, 2013.

ANDRADE, D. F.; SORRENTINO, M. Dialogue as a Basis for the Design of Environmental Pedagogies. Journal of Education for Sustainable Development. v. 8, n. 2, p. 143-154, 2014b.

ANDRADE, D. F.; SORRENTINO, M. Estamos prontos para ouvir "não" e respeitá-lo? As limitações nas relações de participação entre o ocidente e outras culturas. In: CONFERÊNCIA INTERNACIONAL DE EDUCAÇÃO AMBIENTAL E SUSTENTABILIDADE: o melhor de ambos os mundos, 6., 2014, São Paulo. Anais [...]. São Paulo: Sesc São Paulo, 2014a.

ARAGÃO, A. L. A.; NAVARRO, A. Diálogos em Diálogo: David Bohm, Paulo Freire e Mikhail Bakhtin. Educação em Questão, v. 19, n. 5, 2004.

AVANZI, M. R. Tecido a muitas mãos: experienciando diálogos na pesquisa em educação ambiental. Tese (Doutorado em Educação) - Universidade de São Paulo, São Paulo, 2005.

BOHM, D. Diálogo: comunicação e redes de convivência. São Paulo: Palas Athena, 2005.

BOHM, D. A totalidade e a ordem implicada. Tradução de Mauro de Campos Silva. São Paulo: Cultrix, 1980.

BRASIL. Lei n ${ }^{\circ}$ 12.612, de 13 de abril de 2012. Declara o educador Paulo Freire Patrono da Educação Brasileira. Diário Oficial União, Brasília, DF, n. 73, seção 1, p.1, 2012.

BUBER, M. Do diálogo e do dialógico. Tradução de Marta Ekstein de Souza Queiroz e Regina Weinberg. São Paulo: Perspectiva, 2014.

BUBER, M. Eu e Tu. 2a ed. São Paulo: Cortez \& Moraes, 1979.

FIGUEIREDO, J. B. A. As contribuições de Paulo Freire para uma educação ambiental dialógica. Anped, 29a RA. GT Educação ambiental, 2006. Meio digital: <http://arquivos.ambiente.sp.gov.br/cea/cea/GT22_2184.pdf> Acessado em 12 de fevereiro de 2018.

FIGUEIREDO, J. B. A. Educação Ambiental Dialógica e Representações Sociais da Água em Cultura Sertaneja Nordestina: Uma contribuição à consciência ambiental em Irauçuba - CE (Brasil). Tese (Doutorado em Ecologia e Recursos Naturais) - Universidade Federal de São Carlos, São Carlos, 2003.

FÓRUM GLOBAL DAS ONGs. Tratado de Educação Ambiental para Sociedades Sustentáveis e Responsabilidade Global. Rio de Janeiro: 1992. Disponível em: <http://portal.mec.gov.br/secad/arquivos/pdf/educacaoambiental/ tratado.pdf>. Acesso em: 25 mar. 2014.

FREIRE, P. Extensão ou comunicação? 8ª ed. Rio de Janeiro: Paz e Terra, 1983.

FREIRE, P. Pedagogia do Oprimido. 10ª ed. Rio de Janeiro: Paz e Terra, 1981.

FREIRE, P.; SHOR, I. Medo e Ousadia: O cotidiano do professor. Rio de Janeiro: Paz e Terra, 1986. 
ISAACS, W. Accessing genuine dialogue. The watercooler, v. 6, n. 4, 2012.

ISAACS, W. Dialogue and the art of thinking together: a pioneering approach to communicating in business and in life. New York: Doubleday, 1999.

ISAACS, W. Taking Flight: Dialogue, Collective Thinking, and Organizational Learning. Organizational Dynamics v. 22, n. 2, p. 24-39, 1993.

KANTOR, D.; LEHR, W. In the Family. San Francisco: Jossey Bass, 1975.

LIMA, D. M. A. Educação ambiental dialógica e descolonialidade com crianças indígenas Tremembé: vinculação afetiva pessoa-ambiente na escola Maria Venância. Tese (Doutorado em Educação Brasileira) - Universidade Federal do Ceará, Fortaleza, 2014.

LOGAREZZI, A. J. M. Educação ambiental em comunidades de aprendizagem: uma abordagem crítico-dialógica. In: ASSOCIAÇÃO NACIONAL DE PÓS-GRADUAÇÃO E PESQUISA EM EDUCAÇÃO - ANPED, 33, 2010, Caxambu. Anais eletrônicos [...]. Rio de Janeiro: Anped, 2010. CD-ROM.

LUCA, A. Q.; ANDRADE, D. F. O 'diálogo' como objeto de pesquisa na educação ambiental. In: GUNTZEL-RISSATO, C. et al. Educação ambiental e políticas públicas: conceitos, fundamentos e vivências. Curitiba: Appris, 2013, p. 119-129.

MONTEIRO, R. A. A. O diálogo em processos de educação ambiental: análise das relações existentes entre uma ONG e pescadores artesanais marítimos do litoral paulista. Dissertação (Mestrado em Ciência Ambiental) - Universidade de São Paulo, São Paulo, 2018.

NAVARRO, A. Diálogos e reflexão. Tese (Doutorado em Educação) - Universidade Federal do Rio Grande do Norte, Natal, 2005.

ÓRGÃO GESTOR DA PNEA. ProNEA: Educação Ambiental - Por um Brasil Sustentável. $4^{\mathrm{a}}$ ed. Brasília, DF: Ministério do Meio Ambiente, 2014.

ÓRGÃO GESTOR DA PNEA. Programa nacional de formação de educadoras(es) ambientais: por um Brasil educado e educando ambientalmente para a sustentabilidade. Brasília, DF, 2006.

ROESE, M. W. V. Educação ambiental dialógico-crítica e a conservação da biodiversidade no entorno de áreas protegidas. Tese (Doutorado em Ecologia e Recursos Naturais) - Universidade Federal de São Carlos, São Carlos, 2014.

SILVA, L. P. Conflitos socioambientais: uma proposta de investigação-ação à luz da educação ambiental dialógico-problematizadora. Tese (Doutorado em Ciências Ambientais) - Universidade Federal de Goiás, Goiânia, 2016.

SORRENTINO, M. Educador Ambiental Popular. In: FERRARO JUNIOR, L. A. (Org.). Encontros e Caminhos: Formação de Educadoras(es) Ambientais e Coletivos Educadores. Brasília, DF: MMA/DEA, 2014, v. 3, p. 141-154.

SORRENTINO, M. et al. Comunidade, identidade, diálogo, potência de ação e felicidade: fundamentos para educação ambiental. In: GUNTZEL-RISSATO, C. et al. (Org.) Educação ambiental e políticas públicas: conceitos, fundamentos e vivências. Curitiba: Appris, 2013, p. 36-41. 
SOUZA, S. C. Educação ambiental dialógico-crítica no Pantanal de Mato Grosso: a voz e o silêncio das pescadoras e dos pescadores tradicionais. Tese (Doutorado em Ciências Ambientais) Universidade Federal de São Carlos, São Carlos, 2017.

STEWART, J.; ZEDIKER, K. E.; BLACK, L. Relationships among philosophies of dialogue. In: ANDRESON, R.; BAXTER, L. A.; CISSNA, K. N (ed.). Dialogue: theorizing difference in communication studies. Thousand Oaks: Sage, 2004. 